\title{
Pirataria e Comércio de Escravos em AÇão na Grécia ClásSica e HelenísticA*
}

\author{
David M. Lewis ${ }^{1}$ \\ Tradução de Gabriel Cabral Bernardo**
}

RESUMO: A maioria dos escravos no mundo grego eram não-gregos importados e seus descendentes. Ainda assim, sabemos pouco sobre a inserção de indivíduos da periferia não-grega na escravidão. Muito mais promissor para o estudo dessa inserção na escravidão é um processo numericamente menos significativo: a pirataria, onde a captura e venda de indivíduos principalmente gregos - é extensivamente documentada. A pirataria era tanto uma forma de trabalho em si mesma quanto um meio de se conseguir trabalho. O objetivo desse artigo é explorar, por meio do estudo do trabalho da tripulação pirata, da tecnologia à sua disposição e do destino de suas vítimas, os aspectos pragmáticos de captura e venda, bem como o nível em que a prática de resgatar prisioneiros impedia cativos de comporem o suprimento de escravos.

PAlaVRAS-Chave: Pirataria; Escravidão; Comércio de Escravos; Resgate Trabalho.

O suprimento de escravos dos períodos Clássico e Helenístico compreendia uma rede de rotas de comércio, mercados e mercadores, cujo commodity - seres humanos escravizados - alimentava essa rede por meio de processos variados. Dos muitos mecanismos pelos quais indivíduos podem entrar na escravidão (ver Lewis, 2016, p. 318), virtualmente todos podem ser vistos em jogo no mundo grego, com sua significância flutuando de lugar para lugar e mudando conforme o tempo. Em meio a esse fluxo, entretanto, podemos traçar algumas correntes consistentes e de grande volume de pessoas escravizadas operando a longo prazo. Por exemplo, escravos da Anatólia, especialmente da Frígia, aparecem regularmente em nossas fontes (e frequentemente em números

\footnotetext{
* Meus agradecimentos a Lilah Grace Canevaro, Mirko Canevaro, Edward Harris e Jim Roy por terem lido e comentado rascunhos desse artigo. Meus agradecimentos também a Keith Rutter pelo convite a falar para a Scottish Hellenic Society of Edinburgh (Outubro de 2015) e à audiência por seus comentários. Nenhum dos supracitados deve ser tido como responsável pelas faltas desse artigo. As traduções são minhas a menos que indicado; nos casos em que embarcações são referenciadas com variantes latinas e gregas (e.g. lembus/lembos) tendi a favorecer a versão grega. Finalmente, gostaria de agradecer o Prof. Boris Rankov e o Trireme Trust pela permissão de reproduzir a fig. 1 na p. 119, e ao meu amigo Gabriel Cabral Bernardo pelo convite de submeter esse artigo à Mare Nostrum. Esse artigo é dedicado à memória de meu avô, Lt. Cdr. M. E. Lewis $\mathrm{RN}$.

${ }^{1}$ Professor de História e Cultura Grega no Departamento de Estudos Clássicos da Universidade de Edimburgo, Escócia. E-mail: david.lewis@ed.ac.uk.

** Doutorando em História Social pela Universidade de São Paulo.
} 
significativos) do século VI até o Período Romano, assim como escravos do Mar Negro e da Trácia. ${ }^{2}$

Entretanto, em relação à reconstrução dos processos de escravização e do suprimento de correntes que ligavam essas fontes "bárbaras" a compradores nos mercados das cidades-Estado do Egeu, somos imediatamente confrontados com as limitações de nossas evidências: apesar de detalhada em certos locais, ela é extremamente retalhada quando tomada como um todo, com partes essenciais do quebra-cabeça faltando. 3 De fato, apesar da importância numérica dos escravos trácios e frígios, é quase impossível escrever uma história social de sua escravização inicial e de sua entrada no domínio das transações comerciais, ou ao menos uma detalhada. Temos um caso mais otimista, contudo, em relação a um dos menos numericamente significativos processos de escravização no mundo grego: a pirataria.4 Este artigo explora a entrada de indivíduos na escravidão por meio do esboço dos aspectos práticos do sequestro e venda que, por vários séculos, colocou milhares de indivíduos em uma vida de escravidão. Trabalhos recentes destacaram a necessidade de reconstruir as vidas sociais de escravos, isso por meio do exame de suas redes de interação e experiências que iam além da dialética assimétrica entre senhor e escravo (e.g. Vlassopoulos, 2011). Não possuímos para a Antiguidade o tipo de narrativas que sobreviveram do começo da Idade Moderna, pelas quais indivíduos relataram seu sequestro e venda por corsários bárbaros; 5 nem podemos reconstruir a história social dos escravos em trânsito com nada do detalhe conseguido em, por exemplo, o The Slave Ship: A Human History de Rediker (2007). 6 Mas ao reunir os dados espalhados em nossas fontes, podemos ao menos reconstruir uma estrutura que nos permite compreender melhor os estágios iniciais desse ramo do suprimento dos escravos, bem como as experiências de indivíduos assim escravizados.

2 Sobre a Anatólia, especialmente da Frígia, ver Lewis, 2011; 2016; 2018a; 2018b, p. 277-286. Sobre o Mar Negro e região do Danúbio: Finley, 1962; Avram, 2007; Fischer, 2016. Sobre a Trácia, ver Velkov, 1964.

3 Tentei uma reconstrução (admitidamente esboçada) do comércio entre a Anatólia e o Egeu em Lewis, 2016; com mais considerações em Lewis, 2018b, p. 277-286.

4 Que a Pirataria não era uma fonte de escravos de primeira importância no mundo grego foi convincentemente mostrado por Garlan, 1987.

5 Vitkus, 2001; ver também Milton, 2004.

${ }^{6}$ Além disso, a duração das viagens do antigo Mediterrâneo Oriental era muito menor que as das rotas atlânticas discutidas por Rediker (ver, em geral, Arnaud, 2005); e não há razão para acreditar em navios escravistas especializados no mundo grego. 
Esse artigo vai tratar desse tópico em questão em duas partes. A primeira parte examina a pirataria grega do ponto de vista da tripulação pirata e analisa seu trabalho, examinando a tecnologia à sua disposição e como ela era usada. Muito trabalho importante foi publicado nos últimos anos sobre várias facetas da pirataria antiga,7 mas uma área notável negligenciada é o da questão pragmática, de como ela acontecia na prática. Várias contribuições sobre os atributos técnicos dessa ou daquela embarcação usadas por piratas foram feitas ao longo de vários anos (ver infra), mas a última tentativa de descrever de forma abrangente como eles eram utilizados foi publicada em $1924 .{ }^{8}$ Aqui ofereço uma revisão atualizada da prática das tripulações piratas, de modo que nossa compreensão desse aspecto do suprimento de escravos possa ser baseada em uma apreciação mais sólida de seus detalhes práticos. A segunda parte considera o destino das vítimas de sequestro, abrangendo também a mercantilização dos cativos e suas chances de resgate ou libertação. Nenhum acadêmico nos proveu uma análise mais sofisticada da pirataria grega do que Vincent Gabrielsen, cujo trabalho, entre outras coisas, tratou do tópico do "mercado de resgate". Ele mostrou convicentemente que o resgate de cativos era mais lucrativo do que sua venda para a escravidão (Gabrielsen, 2003, p. 392-395). Mas outras considerações além do lucro influenciavam a decisão de se envolver em negociações de resgate, isso ao invés de fugir com os cativos e vende-los, e essas considerações vão compor o foco da segunda parte. Isso, creio, vai contribuir para uma compreensão mais refinada das circunstâncias que ditavam se cativos entrariam nas correntes mais amplas do comércio de escravos ou se reuniriam com seus parentes.

\footnotetext{
7 Sobre a faceta política/historiográfica, ver Avidov, 1998; de Souza, 1999; Wiemer, 2002; Criscuolo, 2013. Sobre a faceta socioeconômica, ver Gabrielsen, 2001; 2003; 2013a; 2013b. Para abordagens comparativas, ver Rauh, 1997. Ver também Perrier, 2008 e os volumes editados recentemente de Braccesi, 2004; Grieb e Todt, 2012; Jaspert e Kolditz, 2013.

8 Ormerod, 1924, p. 13-58. Ferone, 1997, p. 117-137 contém um capítulo intitulado "As Embarcações e as Técnicas de Assalto", mas discute mais profundamente os tipos de embarcações. Discussões parciais úteis podem ser encontradas em Casson, 1958 e Beresford, 2013, p. 238-257.
} 


\section{A Tripulação Pirata e seu Trabalho}

O fenômeno da pirataria no Mediterrâneo antigo e mares adjacentes esteve longe de ser uniforme. ${ }^{9}$ Suas formas mais proeminentes no Egeu clássico e helenístico, entretanto, compartilhava alguns traços em comum e surgiu de estruturas socioeconômicas comparáveis. Essas estruturas eram bem difundidas no Egeu antes de 500 a.C. e persistiram em várias regiões depois disso. Foram as últimas décadas do século VI a.C. que viram a emergência de grandes frotas de trirremes, cuja eficácia se baseava em estruturas fiscais de crescente complexidade, um fenômeno que se desenvolveu paralelamente a processos de formação do Estado em muitas das cidades-Estado mais avançadas. Essas frotas eram estatais, suas tripulações assalariadas e suas atividades determinadas pela política de Estado. Antes desses desenvolvimentos, a violência naval era em sua maioria um assunto privado: galés tipicamente menores que trirremes (como os pentekontoroi e triakontoroi) eram possuídas e equipadas por membros da elite para expedições de saque, as mesmas que poderiam ser recrutadas pelos Estados emergentes em tempos de guerra, mas não eram frotas da pólis (ver van Wees, 2013).

Como Gabrielsen mostrou, o período entre o final do século VI e começo do $\mathrm{V}$ representa um ponto de virada, um que viu as sociedades gregas reunidas em dois campos. ${ }^{10}$ De um lado, foram as pólis desenvolvidas politicamente e economicamente que mantiveram frotas estatais e fizeram o exercício da violência naval um monopólio público. Do outro, foram comunidades mais tradicionais que se agarraram àquilo que Scholten (2000, p. 2) chama de "código arcaico de autosserviço econômico livre e predatório". Nessas regiões, membros da elite ainda organizavam viagens de verão para saquear da mesma forma que as descritas por Homero - foi o conservadorismo social, não a crise social que se responsabilizou pela associação entre pirataria e regiões como Creta e Etólia até mesmo o Período Helenístico (cf. Thuc. 1.5.3). ${ }^{11}$ Além da Grécia propriamente

\footnotetext{
9 Sobre a variedade de suas formas, ver Garlan, 1978. Sobre a pirataria no Mar Negro, ver Tsetskhladze, 2000-1.

10 Gabrielsen, 2001, p. 115-228; 2003, p. 401-403; 2013a, p. 138-147.

${ }^{11}$ Cf. Gabrielsen, 2003, p. 403: "No final das contas, portanto, não foi nem a opressão política nem a pobreza que criou o predador. De fato, historicamente, ele esteve presente por todo o tempo e continuou a gozar de uma existência próspera". Sobre a pirataria como ponta de lança das elites em regiões tradicionalistas, não de excluídos sociais, ver Gabrielsen, 2013, p. 138: "há evidências o suficiente para mostrar que o berço da pirataria estava situada nos escalões mais altos da 
dita, estruturas sociais semelhantes e códigos comportamentais existiam no mar Adriático; o relato de Políbio (2.8.8) sobre os ilírios sob Teuta nos provê de um paralelo próximo para um Estado nascente que ainda não tinha estendido seu alcance sobre navios de guerra e seu uso. Sua resposta à chocada embaixada romana - de que não era o nomimon dos monarcas ilírios impedir seus súditos de se enriquecer no mar - é sintomático de uma visão de mundo arcaica mais ampla, que via o saque de estrangeiros por indivíduos privados como além do alcance da autoridade central. ${ }^{12}$ Desde um período bem anterior os etruscos (tirrênios) estiveram envolvidos em incursões de saque tanto no mar Adriático quanto no Egeu, e aparecem como uma preocupação séria da política atenienses no século IV a.C. (Giuffrida Ientile, 1983).

Uma exceção nessas formas tradicionais de pirataria foi a eflorescência da pirataria na Cilícia durante os séculos II e I a.C.: sua composição social era bem diferente, um produto do estresse causado por mudanças tectônicas entre os Estados helenísticos do Mediterrâneo Oriental. Como Nicholas Rauh (1997) mostrou, os piratas cilícios atraíram elementos das plebes marítimas mediterrânicas de um modo não diferente da pirataria atlântica do século XVIII; suas táticas começaram, entretanto, em linhas tradicionais e apenas depois se desenvolveram para imitar aquelas de um Estado estabilizado. ${ }^{13} \mathrm{O}$ período coberto por esse estudo, portanto, viu tripulações piratas de uma variedade de regiões a solta no Egeu e operando por uma variedade de motivações, com mudanças diacrônicas na intensidade de incursões nessa ou naquela região.

\subsection{Galés Piratas: As Ferramentas do Ofício}

A tecnologia nas mãos de tripulações piratas refletia as estruturas sociais tradicionais das quais emergiu muito dessas atividades. Já no século V a.C.,

estrutura sociopolítica, por mais que os chamemos de elites privilegiadas aristocráticas ou detentoras de poder. Pode mesmo ser possível que muitas das pessoas que tripulavam as embarcações piratas vinham das fileiras de destituídos e oprimidos. Ainda assim, os que comandavam os recursos necessários para possuir, manter e operar essa embarcação, e também para organizar expedições de saque, quase certamente pertenciam a uma distinta classe social mais alta".

${ }^{12}$ Ver Davies, 2004 para um estudo de caso, focando na carreira do chefe guerreiro ilírio Demétrio de Faro.

${ }^{13}$ Sobre a Cilícia como um Estado fora-da-lei, ver Avidov, 1998; mas a aquisição gradual dos cilícios de aparatos semelhantes aos estatais não significa que sua reputação pela pirataria deva ser desconsiderada como chauvinismo e propaganda romana. 
quando descreve os navios da Guerra de Troia, Tucídides (1.10.4) se refere a eles como não sendo semelhantes aos navios modernos da sua época, $\dot{\alpha} \lambda \lambda \dot{\alpha} \tau \tilde{\varphi}$ $\pi \alpha \lambda \alpha \iota \tilde{\varphi}$

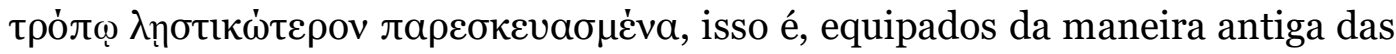
embarcações piratas. Seu tamanho pequeno (raramente precisando de mais do que 50 remadores) e construído levemente (raramente precisado de aríetes de bronze: ver infra) se adequavam perfeitamente às necessidades de seus utilizadores: velocidade, agilidade e discrição. Além disso, o costume arcaico de dividir o butim igualmente (depois de separar os prêmios escolhidos pelos líderes) significava que tripulações maiores levavam a porções individuais menores. ${ }^{14}$ Ainda assim essas embarcações estavam longe de serem antiguidades, nem seu desenvolvimento tecnológico terminou no Período Arcaico. Vários novos desenvolvimentos ilustram refinamentos contínuos dessas tecnologias arcaicas para realizar otimamente seu papel mais especializado nos períodos Clássico e Helenístico como predadores marítimos, cujas presas eram navios de transporte e comunidades costeiras. ${ }^{15}$ Estados também achavam essas embarcações úteis para guerra irregulares. ${ }^{16}$ Por esses motivos, tais embarcações estavam, como J. K. Davies (1984, p. 286) coloca adequadamente, "na vanguarda do progresso militar”. Quatro tipos de embarcação sem convés pedem um comentário mais específico: hemiolia, myoparon, lembos e liburna.

O hemiolia ("de-um-e-meio") é mencionado pela primeira vez em fontes do final do século IV a.C. O covarde estereotípico de Teofrasto (Char. 25.2) é alguém que, quando no mar, imagina que os promontórios que entram no campo de visão são hemioliai. Em termos de detalhes técnicos somos dependentes do nome em si: "de-um-e-meio" deriva com certeza do arranjo dos remos da embarcação, do qual há várias reconstruções possíveis. ${ }^{17}$ Uma solução elegante a dessa charada coloca toda a tripulação remando no mesmo nível, com uma fila inteira de remadores ao longo da amurada e meia fileira em cada um dos lados do centro do navio (onde o vau é mais largo) trabalhando nos intervalos entre as fileiras de remos externas. A figura 1 mostra a reconstrução de J. F. Coates de um

\footnotetext{
14 Van Wees, 1992, p. 299-310. Tal prática permanecia entre os piratas: Ferone, 1997, p. 145-148 15 Navios maiores no começo do Período Arcaico tinham que se comprometer com esse princípio, pois também eram usados no comércio regular: ver Hdt. 1.163 sobre os pentekontoroi foceus.

16 Casson, 1995a, p. 123-135; Gabrielsen, 1997, p. 90-91.

17 Ver Casson, 1958; Morrison 1980; Gabrielsen, 1997, p. 89-90; Ferone, 1997, p. 127-133.
} 
hemiolia baseado nessa hipótese. ${ }^{18}$ Essa reconstrução se adequada à descrição de Hesíquio (s.v. $\dot{\eta} \mu \mathrm{o}$ i ia) do hemiolia como dikrotos, ou seja, com duas fileiras longitudinais de remadores em cada lado (Morrison, 1980, p. 122-123). Arriano (Anab. 6.5.1), em sua discussão sobre a navegação de Alexandre no rio Indo, menciona hemioliai entre os triakontoroi; esses talvez utilizando uma fileira completa de dez remadores e uma meia-fileira de 5 remadores em cada lado, totalizando 30 remadores ao todo. Entretanto, como todos esses tipos de embarcação, o número de remadores não era fixo, podendo variar conforme o uso. É improvável que hemioliai normalmente tivessem aríetes de bronze. ${ }^{19}$

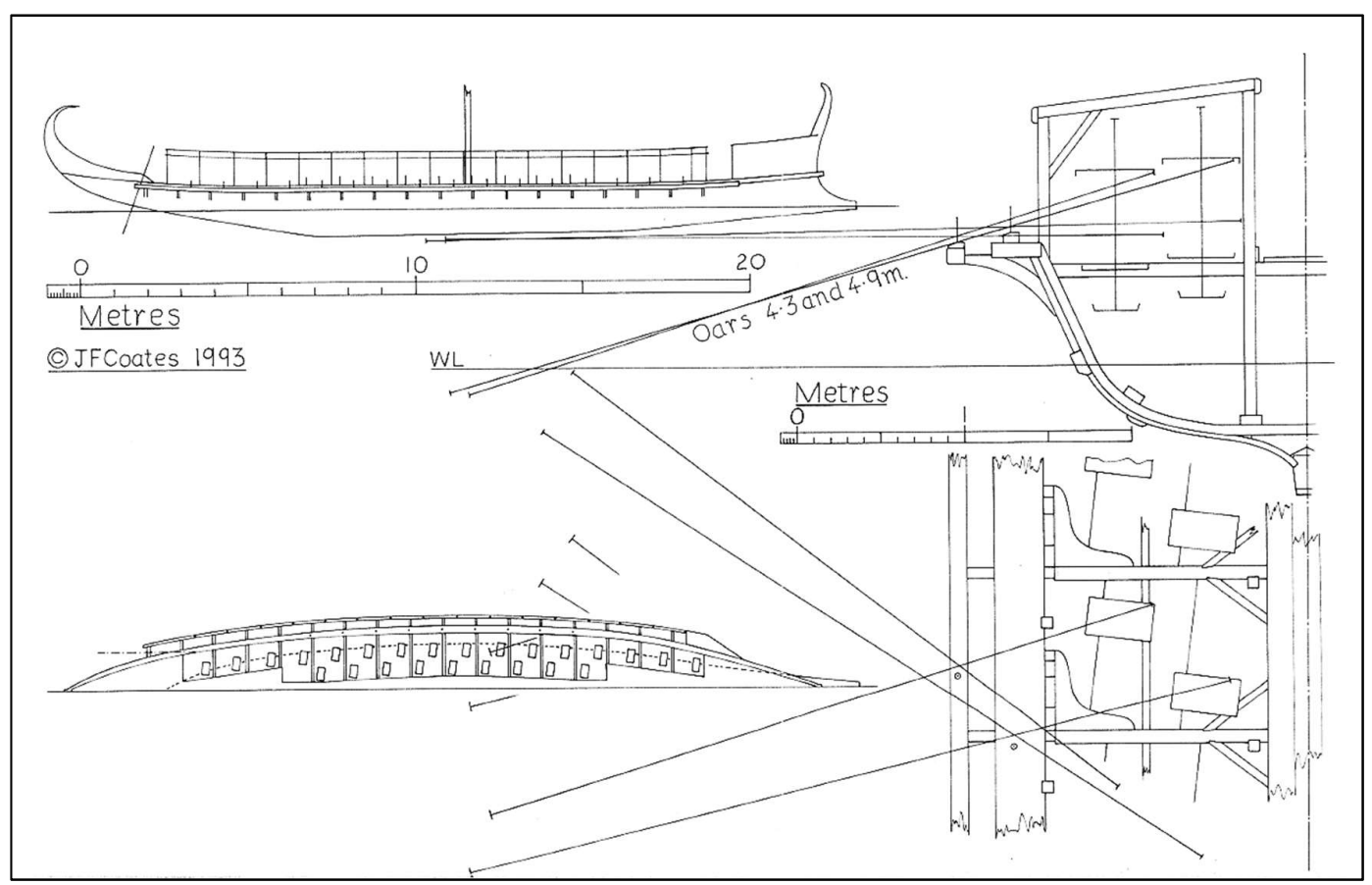

Fig. 1 - Reconstrução de um hemiolia por J. F. Coates. Fonte: Morrison e Coates, 1996, p. 318. Cortesia do Trireme Trust.

Os piratas cilícios começaram seus saques com pequenas embarcações utilizando táticas de pirataria tradicionais (Plut. Pom. 24). De acordo com Apiano

${ }^{18}$ Essa reconstrução seria capaz de chegar a uma velocidade de cerca de 7.5 nós (Morrison e Coates, 1996, p. 317-319.

19 Apiano (Mith. 92) escreve que os piratas cilícios primeiro usaram hemioliai e myoparones, e depois dikrotoi e triereis (por dikrotoi ele provavelmente se refere a embarcações com dois níveis, não tripuladas com duas fileiras em um mesmo nível). Ele apresenta no número de 71 embarcações capturadas e 306 rendidas durante as campanhas de Pompeu (App. Mith. 96). Se Plutarco (Pomp. 28) está correto em reportar que 90 dos navios rendidos tinham aríetes (seguramente os dikrotoi e triereis), então 287 galés sem aríete eram usadas pelos cilícios em 67 a.C., provavelmente compostas (em sua maioria) por hemioliai e myoparones. 
(Mith. 92), eles primeiro usaram hemioliai e myoparones; eventualmente seu poder aumentou de tal maneira que eles desenvolveram forças e táticas de um Estado completo, incluindo grandes navios de guerra e a prática de guerra de sítio. Essas últimas táticas não são de preocupação imediata aqui, dado que elas representam práticas excepcionais ao invés de cotidianas. ${ }^{20}$ Mais relacionado ao nosso ponto é a menção - além dos hemiolia - dos myoparon, outra embarcação pirata pequena e veloz mencionada em várias ocasiões em nossas fontes sobre a pirataria nos séculos II e I a.C., mais notoriamente quando o chefe pirata Heráclio navega quatro myoparones para dentro do porto de Siracusa debaixo do nariz de Verres, o governante ineficaz da Sicília (Cic. Verr. 2.5.96-8). ${ }^{21}$ Sabemos pouco sobre a sua forma, a não ser que ela era uma embarcação de nível único e que normalmente não contava com um aríete em bronze. ${ }^{22}$

O navio por excelência dos saqueadores ilírios era o lembos, um termo que encontramos pela primeira vez nas fontes atenienses do século IV conectado a orçamentos de navios mercantes, ${ }^{23}$ mas que em um contexto ilírio se refere a um tipo específico de embarcação de saque (Medas, 2004). Eles eram pequenos, velozes e úteis para carregar tropas, qualidades que levaram Filipe $\mathrm{V}$ da Macedônia a construir 100 deles, apesar de eles terem sido menos úteis em batalhas navais tradicionais (Plb. 5.109.1-3). Suas tripulações somavam 50 ou menos, e eles eram normalmente embarcações de nível único e abertas; algumas tinham aríetes de bronze. ${ }^{24}$ Eles se tornaram populares entre piratas além do mar

20 Ver Avidov, 1998; cf. Rauh, 1997.

${ }^{21}$ Ver também Plut. Luc. 13.3; Cic. Verr. 2.3.186, 2.5.73, 2.5.89; Sallust fr. 3.8 [Maurenbrecher]; Florus 1.41.6.4-6.

22 Ver n. 19, mas cf. Cic. Verr. 2.1.86-90 para uma exceção. Ver também Casson, 1995a, p. 132; Morrison with Coates, 1996, p. 262. Um myoparon aparece no mosaico de Althiburus: Casson, 1995a, fig. 137. O nome, como os do epaktrokeles, discutido abaixo, é um substantivo composto; ele significa algo como "barco-rato" (um paron é um tipo de barco pequeno: Plb. fr. 193; schol. Ar. Pax 142).

23 Lycurg. Leoc. 17; Dem. 32.6; 34.10; Anaxandrides fr. 34.7 K-A.

24 Em geral, ver Casson, 1995a, p. 125-127. Sobre o tamanho da tripulação: Plb. 2.3.1 tem 5,000 ilírios sobre 100 lemboi, i.e. 50 por lembos. Tito Lívio (34.35.5) menciona um lembos de 16 remadores, i.e. 8 em cada lado. Estrabão (2.99) menciona um lembos equivalente a um penteconter usado pelo explorador Eudoxo e dois barcos menores que pareciam lemboi piratas. Na visão de Estrabão, então, um lembos pirata eram tipicamente menores que um penteconter. Sobre o nível único: Tito Lívio (24.40.2) usa o termo lembus biremibus em uma ocasião; o uso de um modificador deixa implícito que eles normalmente eram embarcações de um único nível. Políbio (5.101.2) escreve sobre $\dot{\eta} \mu$ ió $\lambda$ ıo $\lambda \dot{\varepsilon} \mu \beta$ oı, lemboi eram remados como hemioliai, também evidentemente como uma exceção. Sobre o aríete: pace Casson, 1995a, p. 126 n. 107-108, o fato de Tito Lívio (32.32.9) falar sobre "cinco lemboi e um navio com aríete" deixa implícito que os lemboi não tinham aríetes, mas cf. App. Ill. 7 e Plb. 2.12.3 ( $\lambda \dot{\varepsilon} \mu \beta$ oıৎ ... òvó $\lambda \lambda$ oıৎ), sugerem que lemboi sem aríetes não eram o padrão. 
Adriático.25 Mais para o norte, na costa do mar Adriático, viveram os libúrnios, uma tribo ilíria que deu seu nome ao liburna, outro famoso navio de saque que foi adotada pela frota romana como uma embarcação leve (App. Ill. 3). A versão romana tinha remos em dois níveis, como Lucano (3.534) e Apiano (Ill. 3) deixam claro; um ancestral para esse tipo é talvez visível no relevo de Nesactium, do século V. ${ }^{26}$

Esses quatro tipos de embarcações eram as variantes mais modernas das galés de saque sem convés pequenas e mais antigas que Tucídides conhecia; suas capacidades teriam sido em boa parte semelhantes. Algumas tripulações piratas, entretanto, utilizavam outro tipo de embarcação: variantes rápidas do tipo de galé mercante, uma forma intermediária entre o navio mercante de casco arredondado e a galé de guerra mais esguia (Casson, 1995b). Um tipo mencionado nas fontes do século IV (Aeschin. 1.191; Arist. Int. 16a26) é o epatrokeles, um substantivo composto evidentemente baseado em um tipo mais conhecido de galé mercante, o keles, "cavalo de corrida”, usado por vezes por piratas. ${ }^{27}$ Só o nome é uma evidência de sua velocidade, mas é difícil de estabelecer a diferença entre o epatrokeles e o keles, e devemos nos apoiar nas bases movediças da etimologia. Várias soluções foram propostas, mas talvez o termo signifique nada mais do que “keles-caçador". ${ }^{28}$ As capacidades de tais embarcações eram de alguma maneira

25 Plauto (Bacch. 279-280) descreve um lembos longo e firme perseguindo um mercador. Tito Lívio (37.27) descreve uma frota pequena de lemboi piratas e keletes fugindo para sua base em Mioneso em 190 a.C. Ver também Alcifron1.6.8; Anth. Pal. 5.44. Lemboi eram relativamente espaçosos (Plb. 2.8.4) e podiam ser usados como embarcações mercantis: Casson, 1995b, p. 122. É geralmente suposto que o lembos era a embarcação preferida de piratas etólios (Scholten, 2000, p. 107).

26 Ver Panciera, 1956; Morrison e Coates, 1996, p. 316-317; Höckmann, 1997; Medas, 2004; Mihovilić, 2004.

${ }^{27}$ Sobre o keles: ver Casson, 1995a, p. 160-162; Ferone, 1997, p. 124-126. Sobre seu uso por piratas: Thuc. 4.9.1; Tito Lívio 37.27. Na Etiópica (5.22-5) de Heliodoro e em Tucídides (4.67) piratas usam um tipo de embarcação mercantil rápida, um akation. O akation também era, talvez, usado na Creta helenística (se a emenda de Dindorf em Diod. 31.38 estiver correta), assim como uma embarcação chamada o mydion, sobre a qual sabemos pouco; uma figuração sem refinamento aparece no mosaico de Althiburus (Casson, 1995a, fig. 137). Ver também Ferone, 1997, p. 120-14.

${ }_{28}$ Morrison e Williams (1968, p. 245) conectam a palavra ao verbo epagein e sugerem que significa um pequeno keles que poderia ser embarcado em um navio maior, enquanto que Casson (1995a, p. 161) pensa que o epatrokeles era "provavelmente desenhado com uma capacidade de carga maior" do que o keles. Apesar de uma derivação de epagein ser certa, essa derivação é claramente indireta: epatrokeles deve derivar de uma combinação de keles e do termo epakter, um termo que deriva, por sua vez, de epagein, mas com o sufixo apofônico -ter, e significa "caçador" em grego homérico, no sentido de alguém que "guia" a presa para uma armadilha (cf. Lytle, 2018, p. 83 para o termo na pesca). A variante epaktr-é o grau zero apofônico da tonalidade completa غ̇ं $\alpha \kappa \tau \dot{\varepsilon} \rho$, que é atestada no termo epaktris, usado por Xenofonte (Hell. 1.1.11) para se referir a um navio pequeno. Como Ferone (1997, p. 126) nota, Nicandro (Ther. 823-4) e Hesíquio

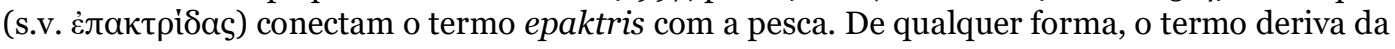


diferentes das galés sem convés descritas acima, com implicações táticas que serão discutidas abaixo.

\subsection{A Galé Pirata em Ação}

Voltemo-nos agora para como as embarcações eram usadas na prática. $\mathrm{O}$ fator de sazonalidade é fundamental: apesar de trabalhos recentes terem mostrado que a velha ideia de uma temporada de navegação fixa de Maio a Setembro é desnecessariamente rígida, a navegação no inverno não poderia ser normalmente tenteada pela maior parte das embarcações aqui consideradas. ${ }^{29}$ Seria, portanto, um erro ver a pirataria grega como uma ocupação em tempo integral, ao menos na maior parte dos casos. É igualmente vital enfatizar a dependência dos piratas em bases terrestres e o seu alcance limitado. Se lê sobre os navios piratas do começo da Idade Moderna cruzando o Atlântico, rodeando a África e navegando para o oceano Índico e para as águas do Mar Vermelho, ficando por vezes no mar por semanas sem ancorarem em terra firma (Konstam, 2003, p. 5-6). Tais feitos eram impossíveis para os piratas gregos que, assim como os capitães dos navios de guerra gregos, tinham que atracar suas embarcações quase que diariamente. $3^{0}$

Ainda que o desembarque em terra firme fosse vital, sabemos pouco sobre o conhecimento que os piratas gregos tinham de boas bases. O orador de [Dem.] 7.3 afirma que "todos os piratas tomam lugares pertencentes a outros povos e os fortificam, e então deles fazem mal a outros”. De fato, várias bases piratas são conhecidas das fontes. ${ }^{31}$ Algumas dessas foram de fato fortificadas:

perseguição da presa, e como tanto Platão (Laws 823e) quanto Aristóteles (Pol. 1256a35-1256b1) assemelham a pirataria com a caça de animais, não fica claro se o termo epaktrokeles deveria ser associado mais com a caça da presa (humana) ou com um tipo específico de embarcação pesqueira (meus agradecimentos a Mirko Canevaro pela discussão do termo).

29 Beresford (2013, p. 237-243; mas cf. p. 248-255: alguns piratas de fato conseguiam operar de maneira limitada no inverno). "[...] saqueadores etólios individuais estavam, nesse ponto, habituados a zarpar no começo da primavera para assediar territórios hostis e navios de carga, assim como os ilírios" (Scholten, 2000, p. 150).

${ }^{30}$ Seu tamanho pequeno e falta de um convés os faziam muito vulneráveis a mares bravios, e.g. Diod. 31.45: uma flotilha de piratas cretenses saqueia Sifnos e navega de noite, mas é naufragado por um vendaval. Cf. Arnaud, 2005, p. 34: "Até mesmo a pirataria, até onde se pode analisar tal fenômeno, ainda mal conhecida em seus detalhes, mas que parece ter sido particularmente costeira, provavelmente não exerceu uma influência maior sobre as travessias de alto mar".

${ }^{31}$ E.g. Alopeconeso (Dem. 23.166), Haloneso ([Dem.] 7.2), Eubeia (Dem. 18.241), Cítno (IG II² 682.10), Mícale (Plut. Mor. 303d), Mioneso entre a Tessália e Eubeia (Aeschin. 2.72), Mioneso em Çifitkalesi Adası (Tito Lívio 37.27; Éforo FGrH 70 F 27), Opus (Thuc. 2.32), Esciro (Plut. Cim. 
Tito Lívio (37.27; cf. Plb. 21.12) escreve sobre uma flotilha pirata de cerca de 50 embarcações, keletes e lemboi, que depois de saquearem a costa de Quios em 190 a.C. e terem partido com "todo o tipo de butim" (cum omnis generis praeda), se depararam com uma frota romana. Os piratas fugiram para sua base no Mioneso, "Ilha Rato" (moderna Çifitkalesi Adası na Turquia), um promontório rochoso que se projeta para o mar entre Teos e Samos (ver Morrison e Coates, 1996, p. 107). Ainda que os romanos os tivessem perseguido os saqueadores à sua base, eles mantiveram distância, não querem chegar ao alcance dos piratas postados nos penhascos do promontório, que estavam presumidamente armados com armas de longo alcance (talvez até com artilharia). Outra base pirata notável era a situada na ilha de Anticítera, entre Cítera e Creta, muito bem localizada nas rotas marítimas que passavam entre Creta e o sul do Peloponeso. Essa foi parcialmente escavada. $3^{2}$

De qualquer forma, o ponto importante de se enfatizar é a dependência profunda dos piratas em bases terrestres. Quando os atenienses enviam uma força naval para a Cária e Lícia em 430/29 a.C., para impedir que piratas peloponésios continuassem usando-a como base para saques de navios de carga comerciais que entravam no Egeu da Fenícia e Fáselis, suas ações pressupunham que não era nada prático para esses piratas operarem do Peloponeso em si (Thuc. 2.69; cf. 8.35). Eles precisavam de uma base mais próxima de suas zonas de caça. 33 O princípio é iluminado em detalhes incomuns em uma inscrição de Siros, datada do começo do século I a.C. (IG XII 5.653 = Bielman, 1994, no. 52), que honra um cidadão da vizinha Sifnos. Notícias de piratas chegam em Siros e fica claro que eles tinham ancorado próximo do território de Sifnos (1. 12-13). Eles capturaram dois escravos, Numênio e Botris, e os desembarcaram em um lugar chamado Eskhatia (1. 25-28); os piratas então desembarcaram em uma ilha oposta ao território de Sifnos (linhas 28-29). Numênio escapou, foi capturado pelo honrado e devolvido a seu mestre em Siros (1. 29-33). O ponto-chave para nossos objetivos aqui é que o ataque dos piratas era dependente da tomada de

8.3), Ilhas Lípari (Tito Lívio 5.28.2), Tragia (Strab. 14.1.7) e Farmacusa (Plut. Jul. 2). Para a rede cilícia de bases terrestres ver Plut. Pomp. 24.3.

$3^{2}$ Ver Johnston et al., 2012; Baika, 2013, p. 277-283. Os ródios lançaramuma expedição contra Anticítera em meados do século III a.C. (Jacopi, 1932, p. 169, no. 1), quase certamente como uma medida antipirataria. Ver Bresson, 2007; Sekunda, 2014.

33 As embarcações de piratas gregos confirmam, assim, as limitações mais amplas do uso de galés mediterrânicas (ver Pryor, 1995). 
ilhas pequenas, presumivelmente inabitadas próximas dos alvos principais, e de seu uso como bases, muito semelhante ao modo descrito por Pseudo-Demóstenes (7.3). Essa dependência de uma "costa aliada" era compartilhada por Rodes, o prostates ("protetor") naval, cuja tecnologia e táticas não eram muito diferentes das dos piratas: Rodes estabeleceu uma rede de bases terrestres, espalhadas por todo o Egeu, que forneciam a infraestrutura militar para expedições antipirataria. 34

Como visto anteriormente, os piratas gregos ou perseguiam embarcações no mar ou faziam incursões anfíbias em cidades costeiras. Não podemos determinar a frequência relativa de um ou de outro, mas nossas evidências pendem mais para a última - ainda que elas tendessem a ser ocasiões maiores, mais prováveis de serem registradas e de produzirem inscrições honoríficas caso alguém negociasse a soltura de prisioneiros.35 Uma coisa é certa: era menos provável que uma embarcação pirata sozinha realizasse uma incursão anfíbia do que uma flotilha de vários navios operando em conjunto. ${ }^{6}$ Dependendo do seu tamanho, um assentamento costeiro seria um alvo muito arriscado para um corsário solitário (ainda que incursões rápidas para o interior fossem menos arriscadas); e mesmo quando nos são noticiados ataques de várias embarcações, eles tendem a acontecer à noite, quando o elemento de surpresa está ao lado dos piratas.37 Se a flotilha fosse grande o suficiente, mesmo vilas relativamente grandes podiam ser atacadas: uma inscrição do século III a.C. registra um ataque em Teos no qual os piratas sequestraram um grupo de cidadãos e cobraram resgate de toda a vila em troca de seu retorno em segurança (SEG 44.949).38 Outra inscrição (SIG3 520 = Bielman, 1994, no. 26) registra a captura de cerca de 280 pessoas de Aulon em Naxos por corsários etólios. Algumas comunidades costeiras visadas por piratas se deram melhor: durante um ataque noturno de piratas no porto de Thera, a guarnição ptolomaica foi capaz de repelir os corsários de uma área onde viviam cerca de 400 pessoas (IG XII.3 supp. no. 1291). Em uma

34 Gabrielsen, 1997, p. 40-42. Sobre as medidas antipirataria, ver também Zambon, 2004.

35 Pace Casson, 1991, p. 178, embarcações mercantes frequentemente eram alvos muito lucrativos, e.g. Lys. 23.25; Dem. 24.11-12; [Dem.] 34-37; Teopompo FGrH 115 F 292; cf. Filocoro FGrH 328 F 162 com Bresson, 2000, p. 131-149

${ }^{36}$ Sobre as flotilhas, ver e.g. Hom. Od. 14.248; cf. Thuc. 6.104; IG XIII.3 supp. No. 1291.9; Arr. Anab. 3.2.3; Diod. 16.81.3, 20.97.5, 28.1; Plb. 5.95.1; Tito Lívio 37.11.6; 37.27.

37 E.g. Hdt. 6.16.2; IG XII.3 supp. no. 1291.14; SIG3 521.5.

${ }^{8}$ Şahin, 1994; Hamon, 2018. 
escala menor temos o ataque da vila de Aigale em Amorgos pelo pirata Soclidas e sua tripulação, em meados do século III a.C. (SIG3 521 = Bielman, 1994, no. 38). Eles fizeram um ataque noturno na região interiorana mais próxima e levaram mais de 30 pessoas; eles então roubaram um navio de um homem chamado Dorio e afundaram os outros navios no porto. Só sabemos sobre esse episódio porque dois dos cativos conseguiram negociar a soltura de cidadãos cativos por Soclidas (muito provavelmente por um resgate generoso, cf. Roy, 2012, p. 53), e foram honrados por seus esforços com uma inscrição. Se essa barganha não tivesse sido realizada, os homens, as mulheres e as crianças sequestradas teriam certamente terminado no mercado escravo de alguma cidade ou vila costeira grega.

Perseguir um navio mercante no mar apresentava um prospecto diferente, um no qual a habilidade naval da tripulação era um fator crucial. 39 Mas também devemos ter em mente o elemento inconstante do tempo. É importante notar uma disparidade tecnológica básica entre o caçador e a presa. A embarcação pirata tinha a vantagem do tempo calmo: mercadores dependentes das velas eram alvos fáceis para predadores cujos remos os permitiam operar eficientemente em tais condições, como o seguinte epigrama ilustra:

Faz estremecer aos navegantes os Cabritos no crepúsculo, mas a Píron é odiosa, mais do que a tempestade, a calmaria.

Pois o navio imóvel e preso é assim tomado pelo rápido e impetuoso birreme pirata, e se da tempestade ele fugiu, na calmaria pela morte se acabou. Ah! Funesto, terrível e desafortunado ancoradouro!40

Por outro lado, mercadores poderiam navegar com maior facilidade em mares agitados, em condições que eram extremamente perigosas para as embarcações menos resistentes ao mar, particularmente as embarcações de saque sem convés (Beresford, 2013, p. 245). Entre esses dois extremos, o resultado poderia pender para qualquer um. Uma taça de figuras negras do final do século VI da Ática mostra uma ilustração notável desse cenário. Ela retrata uma perseguição entre

39 Amadores que fizeram tentativas de pirataria poderiam acabar mal (ver Joseph. BJ 3.9.2 com Ormerod, 1924, p. 30-31).

${ }^{40}$ Anth. Pal. 7.640, século I a.C. Ormerod, 1924, p. 16. Cf. Heliod. Aeth. 5.23-24 com Beresford, 2013, p. 246-247; Polieno 3.11.10, 5.13.1. 
uma embarcação de saque sem convés e um navio mercante em duas cenas sucessivas. Na primeira cena, o mercador tem suas velas atadas na verga, presumivelmente por conta de um vento forte. Apesar dessas condições, a galé cai sobre sua presa com suas velas e todos os homens nos remos. Na segunda cena, o mercador se tornou ciente do perigo e desfraldou suas velas em uma tentativa de escapar de seus futuros captores, mas parece ser em vão: alguns dos piratas deixaram seus remos para recolher a vela e se preparam para abordar sua vítima. ${ }^{11}$

Para piratas abordo de galés de tipo mercantes a situação era ligeiramente diferente. Em sua Etiópica, Heliodoro descreve a perseguição de um mercador por piratas usando um dos tipos de galé mercante mencionados acima, um akation..$^{42}$ Seu relato normalmente ilustra uma variação da situação (descrita acima) envolvendo as galés de saque sem convés. Na história, um navio mercante zarpou de Creta; o piloto notou um akation seguindo seu curso e fica reocupado que ele possa estar tripulado por piratas (5.22). Alguns dos passageiros o dizem para não se preocupar: é perfeitamente normal que embarcações menores seguissem o curso de navios mercantes maiores com marinheiros mais experientes. Mas o fato de que a tripulação do akation é de piratas logo fica aparente: a embarcação segue o akation apenas com suas velas até o vento permitir; quando há uma calmaria, o navio mercante é deixado à deriva na água, e os piratas recorrem a seus remos para toma-lo (5.23). Vale a pena ressaltar duas observações sobre essa passagem: primeiramente, o fato de que essas embarcações foram comumente empregadas para o comércio lhes deram um tom estrategicamente valioso de inocência não compartilhado por galés de saque sem convés mais óbvias. Em segundo lugar, sua melhor navegabilidade as fazia mais adequadas para operar em condições de ventania o em perseguições mais prolongadas.

${ }^{41}$ Minha interpretação segue a de Casson (1958, p. 16). Devemos considerar o tamanho diminuto da taça, que requer a compressão da cena. A afirmação de Morrison (e Coates 1996, p. 183) de que as cenas não são relacionadas devido a uma pequena diferença de altura dos remadores de ambas as cenas pressupões, na minha opinião, que o artista adotou uma abordagem extremamente científica.

42 Os romances gregos incluem muitos episódios coloridos envolvendo piratas. Em termos de verossimilhança alguns autores se dão melhor que outros. Por exemplo, Xenofonte de Éfeso (1.13, de maneira um pouco improvável) descreve uma tripulação de piratas fenícios abordo de um trirreme se fazendo de mercadores. Outros são mais realistas em sua pintura da navegação (ver e.g. Cvikel et al., 2014). 
Como a captura final era realizada é algo que não fica claro. Os piratas que mataram Licon de Heracleia no Golfo Sarônico no século IV parecem ter caído sobre suas vítimas com uma chuva de flechas (Dem. 52.5). É possível que um de nossos naufrágios mais bem preservados, o navio de Cirênia, foi um dia alvo de um ataque desses, uma vez que oito pontas de lança foram descobertas sob seu casco (ver Katzev e Katsev, 1986, p. 4-5). Alternativamente, o poderia intimidar a tribulação mercante com uma demonstração de força, mas deixa-la partir se eles evitassem a luta, como Heliodoro descreve em sua Etiópica (5.24). A captura era provavelmente conseguida com arpéus de abordagem, os kheires siderai (“mãos de ferro"), usados como armas navais no Mediterrâneo Oriental desde a Idade do bronze e empregados na guerra naval do Período Clássico.43 Filóstrato (Imag. 1.19.3), de fato, quando descreve a pintura de uma galé pirata, menciona entre seu macabro arsenal os arpéus de abordagem usados para capturar suas presas.

Quando se chegava à perseguição, os piratas tinham que tirar proveito de tudo para ter alguma vantagem sobre sua vítima: uma perseguição longa deixaria os remadores enfraquecidos em seus remos, de modo que havia a necessidade de manter a perseguição a mais curta e certa possível. Um método que os piratas do Egeu do começo da Idade Moderna usavam envolvia esconder sua embarcação atrás de um promontório, buscando por vítimas dos penhascos acima e atacando no momento oportuno. Isso é descrito por um marinheiro inglês chamado Roberts:

[...] eles vão para as Ilhas Fourni, e ficam ali sob a terra alta, mantendo vigia sobre a colina com uma pequena bandeira, com a qual eles fazem um sinal se veem alguma vela. Então eles saem e ficam diante do Canal de Samos, e ali tomam sua presa. Eles esperam da mesma forma em Necaria e Gadronise [...]. 44

A mesma estratégia era conhecida na Antiguidade, e aparece desde Homero. Na Odisseia (4.842-847), os pretendentes conspiram para matar Telêmaco em seu retorno a Ítaca e equipam uma de suas galés:

43 Sobre a Idade do Bronze ver Wachsmann, 1998, p. 317-319. Sobre o Período Clássico ver Polieno 1.40.0; Diod. 13.50.5. Ver Casson, 1995a, p. 121-122.

${ }_{44}$ Hacke, 1699 citado em Ormerod, 1924, p. 17. 
E os pretendentes embarcaram e cruzavam fluentes vias, revolvendo a abrupta morte de Telêmaco no juízo.

Há uma ilha no meio do mar, rochosa, no meio entre Ítaca e a escarpada Samos, Ásteris, pequenina, na qual há portos abriga-nau, um de cada lado; lá esperavam-no, de tocaia, os aqueus.*

Entretanto, sua emboscada fracassa. Como o pretendente Antínoo comenta amargamente:
De dia, vigias sentavam-se pelos picos ventosos, sempre se revezando; quando o sol se punha, nunca em terra descansávamos à noite, mas no mar, com nau veloz navegando, esperávamos a diva Aurora, tocaiando Telêmaco, para pegá-lo e matá-lo; nisso, eis que um deus o levou para casa (Od.16.365-370).45

O truque também é mencionado em vários autores posteriores, em alguns casos explicitamente associados com piratas. ${ }^{46}$ Sua vantagem é óbvia, pois não apenas ela nega à vítima qualquer ciência sobre o ataque iminente até o último momento, como também permite que a perseguição fosse a mais breve possível, deixando à tripulação energia o suficiente para abordar a presa. 47

\footnotetext{
* Nota do tradutor: tradução para o português de Homero. Odisseia. Tradução e Introdução de Christian Werner. São Paulo: Cosac Naify, 2014.

45 Traduções adaptadas de Lattimore. A primeira passagem é notada por Ormerod (1924, p. 19).

${ }^{46}$ Sobre piratas, ver Eur. fr. 669 [Kannicht]; Heliod. Aeth. 5.20. Sobre táticas navais, ver Thuc. 7.4; 8.35; Arr. Anab. 2.1; Xen. Hell. 5.1.27; Hell. Oxy. 4.1; Tito Lívio 37.28; Frontin. Str. 3.10.8. Cf. Beresford, 2013, p. 243-245. Poderia ser uma alusão literal a essa prática que Duris de Samos ( $F G r H ~ 76 ~ F 13)$ faz quando ele compara os etólios à Esfinge sentada sobre uma rocha, agarrando transeuntes.

47 Piratas também poderiam buscar obter alguma notícia sobre alvos particularmente lucrativos. Aparentemente, os habitantes de Corico mantinham ouvidos abertos aos marinheiros ancorados em portos e passavam informações sobre as presas mais ricas e seus destinos a piratas que operavam na região do Mioneso, um refúgio de pirata notável entre Teos e Samos (cf. n. 30). Isso

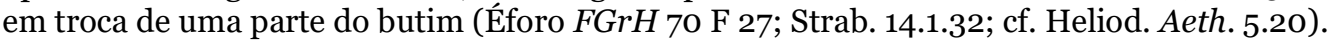




\section{O Destino dos Cativos}

Teofrasto pode ter pensado que a imaginação fértil do homem no mar que tomava qualquer promontório por um hemiolia era um sinal de covardia, mas para os navegantes capturados por uma galé pirata ou habitantes costeiros atacados em um saque pirata, terrores reais ainda esperavam. Isso não quer dizer que a submissão dos mercadores fosse um fait accompli (não obstante a disparidade dos números entre as tripulações dos dois tipos de embarcações, tendendo em favor dos piratas). Xenofonte (Oec. 8.12) afirma que mercadores carregavam armas para se defenderem no mar, e talvez algumas embarcações mercantis maiores, mais bem armadas fossem um alvo muito arriscado para barcos piratas menores operando individualmente. ${ }^{48}$ Certamente, aqueles mercadores que pudessem pagar para fazer parte de um comboio naval organizado pelas cidades como Atenas ou Rodes estavam extremamente bem protegidos contra piratas no mar, que deveriam optar por alvo menos espinhosos (Gabrielsen, 2001; 2013b, p. 73-76). Resistir a piratas certamente fazia muito sentido: no começo da Idade Moderna, tripulações que se rendessem eram frequentemente incorporadas na tripulação pirata 49 - temos, aparentemente, um exemplo disso do Egeu helenístico.50 Ainda assim, a morte ou a escravidão eram destinos mais frequentes na Antiguidade. Em alguns casos, as vítimas eram simplesmente atiradas ao mar para se afogarem pelos piratas mais interessados na carga do que na escravização da tripulação. ${ }^{1}$ Aristóteles (Protréptico fr. 106

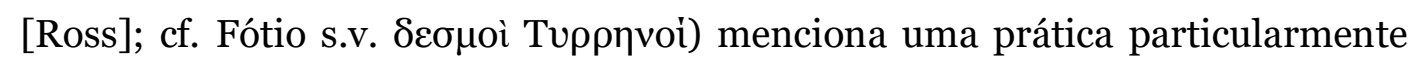
cruel, uma forma de tortura psicológica infligida pelos tirrênios sobre algumas de

48 Ver Gianfrotta, 1981. Ferone (1997, p. 121) aponta para Aristoph. Eq. 761, onde o coro encoraja o Vendedor de Salsichas para figurativamente se proteger "erguendo o golfinho", que Hesíquio (s.v. $\delta \varepsilon \lambda \varphi \tilde{v} v \varepsilon \varsigma$ ) e Eustácio (1221.25) definem como um mecanismo defensivo: "golfinhos" eram pesos metálicos que podiam ser derrubados das amuradas de um navio mercante sobre uma galé pirata para perfurar seu casco.

49 Os marinheiros eram principalmente dos setores mais baixos da classe trabalhadora, cujas famílias não tinham os recursos para resgatá-los, e não havia nas Américas nenhum mercado para marinheiros brancos capturados como para escravos (Rediker, 2004, p. 38-59).

5o IG XII.3 no. 328 = Bielman, 1994, no. 54. Discutido em Ager, 1998.

${ }^{51}$ Anth. Pal. 7.654; Plut. Pomp. 24. Frotas estatais poderiam agir tão cruelmente quanto (Xen. Hell. 2.1.31). Um dos termos gregos para "pirata", katapontistes, significa literalmente "afogador". 
suas vítimas, que teriam sido amarradas face-a-face com corpos que apodreciam..$^{2}$

O principal objetivo das tripulações piratas, entretanto, era ter algum lucro, e isso nos leva ao dilema indicado no começo desse artigo: se os cativos deveriam ser vendidos ou sequestrados. Em uma contribuição importante, Gabrielsen (2003, p. 394) argumentou que essa última opção "era tanto substancial quanto a preferida dos escravos", e de Souza (1999, p. 65) argumentou que a obtenção do resgate "pode mesmo ter sido o principal objetivo de muito da pirataria do Mediterrâneo oriental”. De fato, as evidências são inequívocas no sentido de que a cobrança de resgates pela devolução de cidadãos a seus familiares era muito mais lucrativa do que vende-los a escravidão (Gabrielsen, 2003, p. 393-394). Entretanto, várias considerações pragmáticas, seguindo o padrão das práticas delineadas acima, deveriam ser levadas em conta; e essas podem ter levado alguém a questionar se o resgate era normalmente uma opção prática para tripulações piratas com um casco cheio de cativos recémcapturados.

A primeira consideração é um problema sobre o qual Gabrielsen (1997, p. 85-111; 2001, passim) escreveu bastante: o papel do prostates naval. Apesar de ser verdade que não era o interesse do prostates de erradicar completamente a pirataria, 53 cidades como Rodes mantinham uma ameaça séria contra tripulações piratas, essas que poderiam não ter o tempo disponível para negociar com os parentes de seus cativos e podem ter tido que abandonar a opção mais lucrativa para fugir da perseguição. Como o próprio Gabrielsen (2001, p. 237) escreveu, “estamos demasiadamente focados nas vítimas e cativos dos piratas para apreciar completamente o fato de que o trabalho do saqueador não estava terminado antes que ele tivesse levado seu saque seguramente ao mercado, isso é, sem se deparar com os navios do prostates naval; como uma profissão, leisteia não era completamente livre de periculosidade”.

$5^{2}$ Note que Aristóteles fez um estudo específico sobre os costumes tirrênios (Athen. 1.23d; Heráclides Lembos fr. 44 [Dilts]). Essa forma italiana de tortura é relatada mais vivamente por Virgílio (Aen. 8.485-488).

53 “[...] o perseguidor e os perseguidos estavam emaranhados em uma relação intrincada de dependência mútua dentro da mesma estrutura política e econômica. A eliminação de atividades predatória marítimas significaria, inevitavelmente, que a produção de proteção não mais constituía um motivo de pagamento" (Gabrielsen, 2001, p. 228). 
Talvez mais significativo do que o prostates naval, entretanto, é o fato de que os alvos dos piratas dificilmente eram inofensivos: pequenas pólis e assentamentos costeiros permaneceram armados e perigosos até o Período Helenístico (Ma, 2000, especialmente p. 345-361). Inscrições relatando incursões de piratas em comunidades costeiras mostram isso. SEG 24. 154 (= Bielman, 1994, no. 24; cf. SEG 25.155 = Bielman, 1994, no. 30) honra um estratego ateniense em Ramnonte que protegeu a região interiorana durante um ataque pirata. Apesar de algumas pessoas terem sido capturadas, ele conseguiu resgata-las, mas a lista de suas preparações militares mostra contra o que os piratas avançaram: uma guarnição junto de kryptoi estacionados em pontos estratégicos, bem como torres de vigia e cães. IG XII.3 supp. no. 1291, mencionada cima, descreve coo uma guarnição ptolomaica repeliu com sucesso um ataque de piratas em Thera. $S I G^{3} 521$ (= Bielman, 1994, no. 38), também mencionada acima, descreve um ataque do pirata Sóclidas e de sua tripulação a Amorgos; o fato de que eles afundaram todos os navios no porto deixa implícito que os habitantes locais não teriam se retraído impotentemente, mas teriam perseguidor os piratas se tivessem os meios. IG XII.3 171 (= Bielman, 1994, no. 51) é particularmente rica em detalhes, e descreve uma incursão pirata sobre o território de Éfeso na qual pessoas e propriedades foram levadas das imediações do templo de Ártemis Muníquia. Quando informação e fornecida pelos efésios, indivíduos da ilha próxima de Astipaleia zarpam contra os piratas, capturam muitos deles e resgatam os cativos efésios. Os piratas foram punidos "conforme era adequado à sua perversidade". 54 Esse exemplo mostra que piratas, apesar de terem cativos valiosos em seu poder, não estavam necessariamente em uma posição de segurança. Pode ser notado que a posição da tripulação pirata seria muito menos segura uma vez que o resgate tivesse sido acordado e os cativos devolvidos a seus parentes; pois nesse ponto os piratas teriam perdido sua principal vantagem, que impedia uma ação retributiva por parte da comunidade vitimada. A Quios helenística, de fato, parece ter mantido uma força de leistophylakika ploia, embarcações especializadas na proteção contra piratas (Skarlatidou, 1993, p. 155-158). O que esses exemplos ilustram é que em muitos casos os piratas não estavam seguros o suficiente em sua posição para esperar e

54 Gabrielsen (2003, p. 398) sugere que eles foram vendidos para a escravidão. Alternativamente, eles podem ter sido executados. Sobre as punições de piratas, ver Ferone, 1997, p. 154-156. 
negociar um acordo de resgate lucrativo, mas tinham que partir apressadamente.55 Foi talvez apenas em casos excepcionais que os piratas puderam fazê-lo.

Em segundo lugar está o ímpeto do qual a decisão de cobrar resgate emergiu. As evidências epigráficas contêm poucas instâncias de piratas claramente visando o resgate desde o começo. Uma exceção muito boa (e rara) é SEG 44.949, que data do século III a.C., que registra a lista de um resgate colossal (10\% da riqueza dos cidadãos) de Teos: os piratas tinham saqueado a cidade, tomado vários cidadãos e, nas palavras de de Souza (1999, p. 68), "fizeram com que os teenses supervisionassem o seu próprio saque, o que lhes poupou muito tempo, esforço e perigo ao terem o butim coletado e entregue a eles”. Que eles permitiram que os cidadãos reunissem o resgate por quase um mês mostra a confiança em sua posição - a força pirata deve ter sido formidável.

Muito mais comum, entretanto, são os casos nos quais os cativos são levados para serem vendidos na primeira chance, e ou (i) uma terceira parte bem intencionada intervém e negocia seu resgate e devolução, ou (ii) a cidade natal dos cativos despacha uma embaixada à cidade natal dos piratas para conseguir um resgate. Em alguns casos, o resgate não era nem mesmo negociado com os captores, mas estabelecido depois de que os cativos tinham sido vendidos à escravidão. Seus novos donos, farejando uma oportunidade de ganhar muito mais dinheiro com o cativo do que eles tinham pago por ele como um escravo, consentem, e cartas são despachadas para negociar um resgate. 56

A importância da intervenção dos euergetai pode ser vista em Dem. 57.18, onde sabemos que um ateniense capturado no final da Guerra do Peloponeso acabou servindo como escravo em Leucas, na Grécia ocidental. Depois de vários anos na escravidão, durante os quais ele adquiriu um sotaque estrangeiro, ele encontrou por sorte um ator chamado Cleandro, que negociou sua libertação e o seu retorno. Apesar desse caso não envolver piratas, ele mostra como a negociação de resgates podem ter sido iniciadas não entre o captor

55 Os 38 dias de Júlio César em Farmacusa como cativo de piratas cilícios (Plut. Jul. 2.2) ocorreram em uma época quando os cilícios tinham o domínio do mar. As mesmas condições podem ser presumidas no século III e na maior parte do século II a.C. Jim Roy (2012, p. 58) aponta que em $S I G^{3} 521$ (= Bielman, 1994, no. 38) os cativos são parthénoi e gynaikes, e que a ameaça de estupro significava que recuperar as mulheres rapidamente era uma preocupação urgente de suas famílias.

${ }^{56}$ Gabrielsen (2003, p. 394) compara corretamente esse ao destino de Nicóstrato em [Dem.] 53. Sobre esse caso, ver Sosin, 2017. 
original e a família ou pólis do cativo, mas posteriormente por meio da intervenção de uma terceira parte. Várias inscrições do final do Período Clássico do Helenístico sobre a pirataria se enquadram nesse padrão.

Pode ser esse o caso de $I G \mathrm{II}^{2} 284$ (= Bielman, 1994, no. 5), ainda que toda a circunstância por trás dela não seja totalmente clara. Aqui, Atenas honra Cleomis de Metímna por negociar a soltura de vários cidadãos capturados por piratas. Evidentemente, os piratas não tinham iniciado negociações diretamente com os atenienses: a soltura dos cativos foi realizada pela intervenção de Cleomis. Não fica claro se os cidadãos haviam ou não sido vendidos em primeiro lugar. Muito semelhante é $I G \mathrm{II}^{2} 399$ (= Bielman, 1994, no. 6), na qual Atenas honra Euríloco por negociar o resgate e retorno de vários cidadãos atenienses levados a Cidônia, em Creta. A conexão com Creta faz a pirataria uma possibilidade bem provável. Não há menção de venda, mas novamente é a agência de um euergétes que afeta o retorno dos cativos. A situação é comparável a $S I G^{3} 535$ (= Bielman, 1994, no. 31), onde Atenas honra Eumáridas de Cidônia por negociar o resgate e retorno de vários cidadãos que tinham sido capturados por Bucris e levados a Creta. Bucris foi provavelmente um pirata etólio (Scholten, 2000, p. 109), mas não fica claro se ele estava usando Creta como uma base da qual conseguir o resgate com Atenas ou como um mercado para vender seus cativos como escravos - sendo depois que Eumáridas intervém.

Knoepfler, Eretria XI 317.18 (= Bielman, 1994, no. 29), é um decreto de Erétria honrando Eudêmo de Acarnânia por libertar prisioneiros erétrios. Na visão de Bielman (1994, p. 113), o cenário mais provável é que os prisioneiros eram cativos de piratas etólios, vendidos na Acarnânia, quando Eudêmo interveio e negociou seu resgate e soltura. $O$ fato de que Eudemo tinha negociado a soltura de alguns, mas não todos os cativos (linha 7) sugere que eles tinham sido vendidos a vários proprietários ao invés de mantidos unidos na expectativa de um resgate coletivo. A situação é mais clara em IG XI 4.1054 (= Bielman, 1994, no. 32): aqui, Teângela honra Semo, um cidadão de Delos que comprou vários escravos, butins de um saque pirata. Semo descobriu que dois deles eram mulheres de famílias distintas em Teângela e as libertou. McCabe, Theangela 1 (= Bielman, 1994, no. 40) é um decreto de Trezena honrando Aristides de Tângela, e se refere à libertação de um indivíduo, Carmadas, que tinha sido escravizado pelos etólios: Aristides, sabendo do destino de Carmadas, de sua própria iniciativa e com custos próprios o comprou e o repatriou. Bielman (1994, p. 149-150), com certeza 
corretamente, vê esses etólios como piratas. Em todos esses casos, não há sinal de que piratas tinham visado os resgates desde o começo; a invés disso, o resgate era negociado posteriormente, pela agência de uma terceira parte.

Além disso, há exemplos onde a pólis dos cativos toma a iniciativa de despachar uma embaixada para a cidade natal dos piratas, com o objetivo de negociar o retorno dos cativos. Em $S I G^{3} 244$ (= Bielman, 1994, no. 26) Aulon, em Naxos, honra vários de seus cidadãos que serviram como embaixadores e asseguraram o resgate de 280 pessoas capturadas em um ataque de etólios. Uma embaixada despachada para assegurar a soltura dos cativos também é mencionada em um decreto parcialmente danificado da Samotrácia (IG XII 8.159 = Bielman, 1994, no. 47). IG XII.3 no. 328 (= Bielman, 1994, no. 54) é um document difícil, uma carta referente aos indivíduos de Tera que tinham sido capturados por piratas de Allaria, em Creta. Três anos depois, eles tinham sido libertos e recebido terras em Allaria. Os cativos parecem ter se unido aos piratas em suas atividades, apesar de eles aparentemente não compartilhassem do butim. Dados os nossos objetivos, o ponto-chave é que a inscrição documenta esforços diplomáticos para repatriar cativos de Tera em um ponto muito posterior na história. 57

Finalmente, temos o exemplo, mencionado acima, de $S I G^{3} 521$ (= Bielman, 1994, no. 38), quando o ímpeto de estabelecer um acordo de resgate

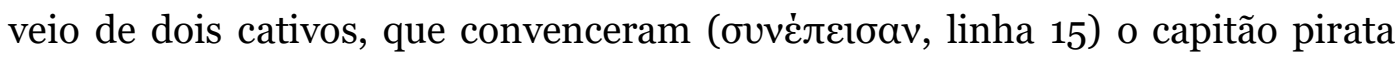
Sóclidas a libertar os cativos, presumivelmente por um resgate. Novamente, vemos que o ímpeto de negociar um resgate não veio dos piratas, mas de outras partes.

Em suma, a maioria de nossas inscrições mostra tripulações piratas partindo rapidamente com seu grupo de cativos e os vendendo à escravidão. Uma questão rapidamente emerge: a evidência é representativa da realidade? Não, do ponto de vista de Gabrielsen (2003, p. 394): “o que de fato temos são registros de casos que, por sua própria natureza, eram habitualmente considerados meritórios de serem publicitados em inscrições: isso é, a intervenção de benfeitores, coletivos ou indivíduos. O que nos falta completamente (e provavelmente nunca teremos) são evidências epigráficas do número presumivelmente muito maior de cativos sendo comprados de volta por suas

57 A discussão completa e uma interpretação nova pode ser vista em Ager, 1998. 
próprias famílias, algum normalmente não publicitado por inscrições”. Dificilmente pode-se discordar disso, ${ }^{8}$ mas é importante adicionar outro ponto: que assim como o registro epigráfico não captura tais instâncias de negociações privadamente negociadas, também não deve capturar as instâncias em que cativos eram vendidos à escravidão. $\mathrm{O}$ argumento sobre o que o registro epigráfico deixa no escuro pode, assim, usado de ambas as formas.

Meu ponto não é que conclusões certas sobre a frequência dos resgates ou venda podem ser obtidas de nossas fontes. Ao invés disso, é que a possibilidade de venda não deveria ser subestimada, e que o risco, bem como o lucro, governava as decisões da tripulação pirata em qualquer instância. O fato de que pólis helenísticas gastaram muitos esforços em proteger seus cidadãos da venda como escravos 59 sugere que a escravidão e a venda eram riscos muito graves.

\subsection{Comercializando Cativos}

Isso nos leva ao último elo na cadeia de suprimento na qual a tripulação pirata tinha um papel direto: a venda de cativos em mercados de escravos. O primeiro problema pragmático dessa etapa do processo é o transporte dos cativos: como foi notado acima, a maioria das embarcações utilizadas pelos piratas (com a exceção das galés de tipo mercante) não eram planejadas para transportar carga. Os keletes e lemboi mencionados por Tito Lívio como operantes no Mioneso em 190 a.C. teriam sido mais adequados para transportar butim do que embarcações como os myoparones e hemioliai (ver n. 25 e 27). De acordo com Hipérides (Sobre a Proteção contra os Tirrênios fr. 166 [Blass]), piratas tirrênios usavam, junto com suas galés, navios especiais chamados komistika ploia, "navios de transporte", que Hesíquio define como embarcações auxiliares para o transporte de butim capturado. Não temos evidências para estratégias similares usadas por piratas gregos - ainda que o fato de que o bando de Sóclidas em $S I G^{3} 521$ ter roubado o navio de Dorio pode, similarmente, ser devido ao seu grupo de 30 cativos, que pode não ter sido fácil de levar na ou nas embarcações nas quais os piratas chegaram. De qualquer forma, a tecnologia à

\footnotetext{
58 Ainda que valha notar um ponto prático: podemos imaginar piratas conduzindo simultaneamente várias negociações com as famílias de cada cativo capturado em um ataque? Isso teria complicado o processo de negociação imensamente.

59 Ver Kvist, 2003 para concessões cretenses de asylia. Ver também Roy, 2012.
} 
disposição dos piratas pode ter influenciado sua preferência pelos cativos humanos ao invés de por outros tipos de butim, pois os primeiros tinham uma razão de volume e peso por valor muito favorável, e poderiam ser rapidamente embarcados antes de uma fuga precipitada (Gavriljuk, 2003, p. 79-80).

A afirmação de Rostovtzeff (1941, p. 196) de que piratas "eram bem vindo em todos os portos comerciais quando apareciam carregados de butim” é insatisfatória por vários motivos. Primeiramente, parece muito uma extrapolação descuidada das notas de Estrabão (14.5.2) sobre a Delos do final do Período Helenístico. Em segundo lugar, ela ignora pólis abertamente hostis como Atenas e Rodes (pelo menos) que não eram amigáveis a tripulações piratas. Em terceiro lugar, é duvidoso que a maior parte dos portos comerciais não ficassem alarmados pela chegada de uma flotilha do tipo de embarcações mencionadas acima, o que fortalece a sugestão do uso adicional de embarcações mercantes mais genéricas para a venda de cativos em outros portos que não os da terra natal das tripulações piratas (e.g. em Creta e na Etólia). Em outras palavras, pirata podem ter tomado embarcações com aparência mais inocente (como o navio de Dorio referida em $S I G^{3} 5^{21}$ ) ou utilizado embarcações mais práticas (como as komistika ploia terrênica) e quisessem comercializar seus cativos em algum lugar além dos portos de sua terra natal. Outra possibilidade, ainda que uma para a qual não temos evidências, jaz nos contatos entre tripulações piratas e vendedores de escravos, que poderiam permitir o comércio do grupo de cativos sem o risco de navegar para algum porto propriamente dito (Gabrielsen, 2003, p. 394). É uma marca da dificuldade da evidência que a significância dessa opção, potencialmente importante, não possa ser avaliada com base nos dados que possuímos. Ainda assim, de fato sabemos de portos recebido piratas e lhes provendo um mercado para butim pirata: duas inscrições atenienses do século $\mathrm{V}$ proíbem explicitamente que pólis aliadas fizessem isso (IG I3 67.7-9; 75.6-10), e no século seguinte sabemos de reclamações de que os tásios e mélios fizeram exatamente isso (Dem. 12.2; 58.56). Como tripulações piratas sabiam onde encontrariam portos e mercados seguros para seus cativos, além de retornar para os portos de sua terra natal?

Uma resposta abrangente não é possível, mas algumas considerações sobre a identidade das tripulações piratas e especialmente sobre a de seus líderes pode sugerir linhas frutíferas de questionamento. Como Gabrielsen mostrou, é um erro ver o contexto social da maior parte da pirataria (pré-cilícia) no Egeu em 
termos de grupos marginalizados ou excluídos. Galés piratas eram, em sua maioria, possuídas, equipadas e suas tripulações lideradas por homens da elite de comunidades gregas que nunca abandonaram as práticas e atitudes de corso privado do Período Arcaico. Sua predileção por saques não deve ser vista como um papel exclusivo. Mesmo em Homero (Od. 1.184) um chefe pirata também podia ser um mercador de metais. Da mesma forma, é bem sabido que mercenários gregos antigos eram recrutados não de um "mercado aberto", mas por meio de redes de xenia aristocráticas (desde então o termo xenos ganhou o significado auxiliar de "mercenário"). Os mesmos indivíduos poderiam transitar entre esses diferentes papeis e identidades conforme e quando preciso. O melhor modo de explicar a situação mais tardia é em termos de continuidades de longaduração desde o Período Arcaico, quando líderes podiam saquear com seus hetairoi, ajudar um de seus xenoi suprindo-o com soldados (eles mesmos e seus hetairoi) em troca de um misthos, e de fato se envolver no comércio.

Essa multiplicidade de papeis entre as que individuais de regiões tradicionais podiam transitar é evidente nas fontes dos períodos Clássico e Helenístico. Por exemplo, não há razões para pensar que as origens sociais de mercenários cretenses - demandados como arqueiros especializados em escaramuças sobre terreno irregular - eram muito diferentes das dos piratas cretenses. ${ }^{60}$ Os archipeiratai do começo do Período Helenístico são outro caso. Sabemos de vários "chefes piratas” servindo como mercenários em guerras dos Reinos Sucessores (ver Gabbert, 1986). Alguns sugeriram que esses eram "expiratas" (Gabbert, 1986, p. 160), mas isso é errar sobre a natureza do problema: os termos gregos leistes e peirates não eram status ou categorizações legais concedidas pela violação da lei internacional, mas termos usados por motivos funcionais conectados com a estratégia de incursões de saque. Isso poderia incluir indivíduos que fizeram dessa sua atividade habitual (i.e. piratas em stricto sensu), mas a mesma terminologia poderia ter sido usada para tropas de cidades em guerra que recorriam a táticas de incursões de saque, ou indivíduos que praticavam incursões de saque por um tempo limitado antes de retornar para métodos de guerra mais "formais".

${ }^{60}$ Sobre o treinamento em táticas de guerra irregular ver Plat. Leg. 625c-626b; Éforo FGrH $70 \mathrm{~F}$ 149. Sobre arqueiros mercenários cretenses ver Thuc. 6.25.2; 6.43; 7.57.9-10; Xen. Anab. 1.2.9; 3.3.7; 3.3.15; 3.4.17; 4.2.27-8; 5.2.29-32; Hell. 4.2.16; 4.7.6; Plb. 4.20.6-12; 4.54-5; 4.67.3; 4.68.3; 5.3.2; 5.14.1; 5.79.10; 17.57.4; 20.85.3; Arr. Anab. 1.8.3-5; 2.7.7-8; 2.9.3; 3.5.6. Sobre a pirataria cretense no geral, ver Brulé, 1978. 
Meu ponto aqui é que não deveríamos assumir que os antigos comerciantes, mercenários e piratas gregos eram sempre ocupações distintas praticadas por diferentes indivíduos. Como Luraghi (2006) mostrou, o mesmo indivíduo poderia transitar entre cada papel. O mesmo provavelmente era verdade em tempos posteriores, e isso pode nos prover uma chave para compreender tanto como tripulações piratas eram capazes de comercializar seu butim em mercados que não os dos portos de suas cidades natal. Pois essas tripulações geralmente não eram (com exceção dos tirrênios) bárbaros estrangeiros intrusos no mundo grego, mas componentes dele há muito estabelecidos. Assim como os empreendedores da elite do Período Arcaico tipicamente viajavam muito e eram bem conectados a seus pares em outros locais do Egeu, seus sucessores nas comunidades gregas tradicionais de períodos posteriores provavelmente tinham conexões sociais em outras regiões e levavam algum conhecimento de promontórios, portos seguros, alvos legítimos e lucrativos e mercados amigáveis. Eram tais conexões que os permitiam permanecer em contato com, por exemplo, reis helenísticos que precisavam de seu conhecimento na guerra irregular; ou mesmo em contato com cidades como Atenas, como o condottiere eubeu e chefe guerreiro Carídemo, que foi acusado de começar sua carreira como mercenário de infantaria leve antes de adquirir um navio pirata e predar aliados atenienses (Dem. 23.148). Etólios e o koinon etólio do século III a.C. eram muito familiares com (e conectados ao) o mundo egeu mais amplo (Funke, 2008). Mês em regiões mais desenvolvidas, a tentação que levava homens a recorrer à vida antiquada de um corsário dificilmente estava fora de questão: foi essa a decisão do almirante foceu Dioníso, depois da Batalha de Lade (Hdt. 6.17), e em séculos posteriores encontramos os chamados líderes piratas de várias pólis, incluindo Mileto (Xen. Hell. 2.1.30), Cálcis (Tito Lívio 31.22), Esparta (Tito Lívio 37.13.11-14.1; Plb. 5.3.7) e Metímna (Arr. Anab. 3.2.4). mesmo na Atenas do século IV, um indivíduo parece ter adquirido um trirreme excedente e rumado com ele para Creta para servir como comandante mercenário (Casson, 1995c). Em tais casos a distinção entre guerra e pirataria era obscura, e um escorregão entre os dois poderia facilmente ocorrer. A diferença não era entre indivíduos que praticavam essas atividades, mas uma questão das táticas, alvos e relações com cidade em guerra em um dado período. 


\section{Conclusão}

Deixar de lado nossa bagagem cultural associada à pirataria atlântica dos séculos XVII e XVIII é crucial para entender o caráter social e operação prática da pirataria no mundo grego antigo. Ao invés de representar crises morais ou econômicas, o corso privadamente organizado era, no geral, uma atividade tradicional que certas comunidades gregas simplesmente nunca abandonaram ainda que os gregos que escreveram a maioria de nossas fontes viessem de comunidade economicamente e politicamente mais desenvolvidas, que consideravam essas práticas atrasas, repugnantes e ilegítimas. Ainda assim, a pirataria era um componente fundamental da economia antiga grega. Ela redistribuía commodities pela força mais frequentemente do que os destruía por completo; mas também comodificava ativamente seres humanos, atirando-os dos navios nos quais navegavam ou retirando-os de comunidades costeiras nas quais viviam e os transformavam literalmente em "capital humano" que poderia ser comercializado no mercado de escravos. Isso não quer dizer que a pirataria era um elemento claramente produtivo da economia antiga: ela certamente aumentava os custos de transação do comércio internacional, ${ }^{61}$ não se preocupando em arruinar as vidas e fortunas de suas vítimas e das comunidades de suas vítimas. De qualquer maneira, o estudo de seus aspectos práticos sublinha sua importância para a história do trabalho no mundo grego, pois não apenas a pirataria envolvia trabalho qualificado, mas também produzia trabalho por meio da escravização de suas vítimas. O mercado de resgate, de fato, até certo ponto, desviou uma proporção desses cativos e os devolveu a seus familiares; mas é mais provável que o carro-chefe das típicas tripulações piratas fosse a escravidão, roubo e assassinato - um objetivo seguido todo verão no Mediterrâneo Oriental por séculos até que a frota de Pompeu acabou com ele em 67 a.C.

Artigo recebido em 21.03.2019, aprovado em 11.04.2019

\section{REFERÊNCIAS BIBLIOGRÁFICAS}

Ager, S. Thera and the Pirates: An Ancient Case of the Stockholm Syndrome? Ancient History Bulletin, vol. 12, 1998, p. 83-95.

${ }^{61}$ As anotações de Bresson, 2016, p. 301-305 são completamente corretas, do meu ponto de vista. 
Arnaud, P. Les routes de la navigation antique: itinéraires en Méditerranée. Paris: Errance, 2005.

Avidov, A. Were the Cilicians a Nation of Pirates? Mediterranean Historical Review, vol. 12, 1997, p. 5-55.

Avram, A. Some Thoughts about the Black Sea and the Slave Trade before the Roman Domination (6 $6^{\text {th }} 1^{\text {st }}$ centuries BC). In: Gabrielsen, V.; Lund, J. (eds.) The Black Sea in Antiquity: Regional and Interregional Economic Exchanges. Aarhus: Aarhus University Press, 2007, p. 239-251.

Baika, K. The Fortification of Shipsheds and Naval Arsenals. In: Blackman, D.; Rankov, B. Shipsheds of the Ancient Mediterranean. Cambridge: Cambridge University Press, 2013, p. 185-209.

Beresford, J. The Ancient Sailing Season. Leiden: Brill, 2013.

Bielman, A. Rétour à la liberté: libération et sauvetage des prisonniers en Grèce ancienne. Athens: École Française d'Athènes, 1994.

Braccesi, L. (ed.) La pirateria nell'Adriatico antico. Rome: L'Erma di Bretschneider, 2004.

Bresson, A. La cité marchande. Bordeaux: Ausonius Éditions, 2000.

. Rhodes, Rome et les pirates tyrrhéniens. In: Brun, P. (ed.) Scripta Anatolica: Hommages à Pierre Debord. Bordeaux: Ausonius, 2007, p. 145-64.

. The Making of the Ancient Greek Economy: Institutions, Markets, and Growth in the City-States. Princeton: Princeton University Press, 2016.

Brulé, P. La piraterie crétoise hellénistique. Paris: Les Belles Lettres, 1978.

Casson, L. Hemiolia and Triemiolia. Journal of Hellenic Studies, vol. 78, 1958, p. 14-18.

. The Ancient Mariners. Princeton: Princeton University Press, 1991.

Ships and Seamanship in the Ancient World. Revised Edition. Baltimore: Johns Hopkins University Press, 1995a.

. Merchant Galleys. In: Gardiner, R. (ed.) The Age of the Galley. London: Conway Maritime, 1995b, p. 117-126. p. 241-245.

A Trireme for Hire (Is. 11.48). Classical Quarterly, vol. 45, n. 1, 1995c,

Crisculo, L. Ptolemies and Piracy. In: Buraselis, K.; Stefanou, M.; Thompson, D. J. (eds.) The Ptolemies, the Sea and the Nile: Studies in Waterborne Power. Cambridge: Cambridge University Press, 2013, p. 160-171.

Cvikel, D.; Kahanov, Y.; Rosen, B.; Saaroni, H.; Galili, E. The Voyage of Leucippe and Clitophon: A New Interpretation. Mariner's Mirror, vol. 100, n. 4, 2014, p. 388-404. 
Davies, J.K. Cultural, Social and Economic Features of the Hellenistic World. Cambridge Ancient History, Vol. VII.1. Second Edition. Cambridge: Cambridge University Press, 1984, p. 257-320.

Davies, J.K. Demetrio di Faro, la pirateria e le economie ellenistiche. In: Braccesi, L. (ed.) La pirateria nell'Adriatico antico. Rome: L'Erma di Bretschneider, 2004, p. 119-127.

de Souza, P. Piracy in the Graeco-Roman World. Cambridge: Cambridge University Press, 1999.

Ferone, C. Lesteia: forme di predazione nell'Egeo in età classica. Napoli: Procaccini, 1997.

Finley, M. I. The Black Sea and Danubian Regions and the Slave Trade in Antiquity. Klio, vol. 40, 1962, p. 51-59.

Fischer, J. Der Schwarzmeerraum und der antike Sklavenhandel. Bemerkungen zu einigen ausgewählten Quellen. In: Frass, M.; Graßl, H.; Nightingale, G. (eds.) Akten des 15. Österreichischen Althistorikertages Salzburg, 20.-22. November 2014. Salzburg: Paracelsus, 2016, p. 53-71.

Funke, P. Die Aitoler in der Ägäis. Untersuchungen zur sogenannten "Seepolitik" der Aitoler im 3. Jh. v. Chr. In: Winter, E. (ed.) Vom Euphrat bis zum Bosporus. Kleinasien in der Antike. Festschrift für Elmar Schwertheim zum 65 . Geburtstag. Bonn: Habelt, 2008, p. 253-267.

Gabbert, J. Piracy in the Early Hellenistic Period: A Career Open to Talents. Greece \& Rome, vol. 33, n. 2, 1986, p. 156-163.

Gabrielsen, V. The Naval Aristocracy of Hellenistic Rhodes. Aarhus: Aarhus University Press, 1997.

- Economic Activity, Maritime Trade and Piracy in the Hellenistic Aegean. Revue des Etudes Anciennes, vol. 103, 2001, p. 219-240.

. Piracy and the Slave Trade. In: Erskine, A. (ed.) A Companion to the Hellenistic World. Oxford: Blackwell, 2003, p. 389-404.

. Warfare, Statehood, and Piracy in the Greek World. In: Jaspert, N.; Kolditz, S. (eds.) Seeraub im Mittelmeerraum. Piraterie, Korsarentum und maritime Gewalt von der Antike bis zur Neuzeit. Paderborn: Verlag Ferdinan Schöningh, 2013a, p. 133-153.

. Rhodes and the Ptolemaic Kingdom: The Commercial Infrastructure. In: Buraselis, K.; Stefanou, M.; Thompson, D. J. (eds.) The Ptolemies, the Sea and the Nile: Studies in Waterborne Power. Cambridge: Cambridge University Press, 2013b, p. 66-81.

Garlan, Y. Signification historique de la piraterie grecque. Dialogues d'Histoire Ancienne, vol. 4, 1978, p. 1-16.

. War, Piracy and Slavery in the Greek World. In: Finley, M. I. (ed.) Classical Slavery. London: Psychology Press, 1987, p. 7-21. 
Gavriljuk, N. The Graeco-Scythian Slave Trade in the $6^{\text {th }}$ and $5^{\text {th }}$ Centuries BC. In: Bilde, P. G.; Hojte, J. M.; Stolbe, V. F. (eds.) The Cauldron of Ariantas: Studies Presented to A. N. Sceglov on the Occasion of his $75^{\text {th }}$ Birthday. Aarhus: Aarhus University Press, 2003, p. 75-85.

Gianfrotta, P. Commercio e pirateria: prime testimonianze archeologiche sottomarine. Mélanges de l'école française de Rome: Antiquité, vol. 93, 1981, p. 227-242.

Giuffrida Ientile, M. La pirateria tirrenica: momenti e fortuna. Rome: G. Bretschneider, 1983.

Grieb, V.; Todt, S. (eds) Piraterie von der Antike bis zur Gegenwart. Stuttgart: Franz Steiner Verlag, 2012.

Hacke, W. A Collection of Original Voyages. London: James Knapton, 1699.

Hamon, P. Tout l'or et l'argent de Téos: au sujet d'une nouvelle édition des décrets sur les pirates et l'emprunt public pour la libération des otages. Chiron, vol. 48, 2018, p. 333-374.

Höckmann, O. The Liburnian: Some Observations and Insights. International Journal of Nautical Archaeology, vol. 26, 1997, p. 192-216.

Jacopi, Giulio. Nuove epigrafi dale Sporadi Meridionali. In: Maiuri, Amedeo (org.) Monumenti di scultura del Museo Archeologico di Rodi. Bergamo: Istituto Storico-Archeologico, 1932, p. 165-256.

Jaspert, N.; Kolditz, S. (eds.) Seeraub im Mittelmeerraum. Piraterie, Korsarentum und maritime Gewalt von der Antike bis zur Neuzeit. Paderborn: Verlag Ferdinan Schöningh, 2013.

Johnston, A., Quercia, A., Tsaravopoulos, A., Bevan, A.; Conolly, J. Pots, Piracy and Aegila: Hellenistic Ceramics from an Intensive Survey of Antikythera, Greece. Annual of the British School at Athens, vol. 107, 2012, p. 247-272.

Katzev, M. L.; Katzev, S. Kyrenia II: Research on an Ancient Shipwreck comes Full Circle in a Full-Scale Replication. Institute of Nautical Archaeology Newsletter, vol. 13, n. 3, 1986, p. 1-11.

Konstam, A. The Pirate Ship 1660-1730. Oxford: Osprey Publishing, 2003.

Kvist, K. Cretan Grants of Asylia: Violence and Protection as Interstate Relations. Classica et Mediaevalia, vol. 54, 2003, p. 185-222.

Lewis, D. M. Near Eastern Slaves in Classical Attica and the Slave Trade with Persian Territories. Classical Quarterly, vol. 61, n. 1, 2011, p. 91-113.

- The Market for Slaves in the Fifth- and Fourth-Century Aegean: Achaemenid Anatolia as a Case Study. In Harris, E. M.; Lewis, D. M.; Woolmer, M. (eds.) The Ancient Greek Economy: Markets, Households and City-States. Cambridge \& New York: Cambridge University Press, 2016, p. 316-336. 
. Notes on Slave Names, Ethnicity, and Identity in Classical and Hellenistic Greece. Studia Źródłoznawcze: U Schyłku Starożytności, vol. 16, 201a, p. 169-199.

. Greek Slave Systems in their Eastern Mediterranean Context, c. 8oo146 BC. Oxford: Oxford University Press, 2018b.

Luraghi, N. Traders, Pirates, Warriors: The Proto-History of Greek Mercenary Soldiers in the Eastern Mediterranean. Phoenix, vol. 6o, 2006, p. 21-47.

Lytle, E. Fishing with Fire: Technology, Economy, and Two Inscriptions. Historia, vol. 67, n. 1, 2018, p. 61-102.

Ma, J. Fighting Poleis of the Hellenistic World. In: van Wees, H. (ed.) War and Violence in Ancient Greece. London: Classical Press of Wales, 2000, p. 337-376.

Medas, S. $\Lambda \dot{\varepsilon} \mu \beta o r$ e liburnae. In: Braccesi, L. (ed.) La pirateria nell'Adriatico antico. Rome: L'Erma di Bretschneider, 2004, p. 129-138.

Mihovilić, K. La situla di Nesazio con naumachia. In: Braccesi, L. (ed.) La pirateria nell'Adriatico antico. Rome: L'Erma di Bretschneider, 2004, p. 93-107.

Milton, G. White Gold. London: Farrar, Straus and Giroux, 2004.

Morrison, J. S. Hemiolia, Trihemiolia. International Journal of Nautical Archaeology, vol. 9, 1980, p. 121-126.

Morrison, J. S.; Williams, R. T. Greek Oared Ships. Cambridge: Cambridge University Press, 1968.

Morrison, J. S.; Coates, J. Greek and Roman Oared Warships. Oxford: Oxbow Books, 1996.

Ormerod, H. A. Piracy in the Ancient World. Liverpool: Liverpool University Press, 1924.

Panciera, S. Liburna: rassegna delle fonti, caratteristiche della nave, sccezioni del termine. Epigraphica, vol. 18, 1956, p. 130-156.

Perrier, A. Brigands et pirates. In: Picard, O., Brunet, M., Couvenhes, J.C., Perrier, A., Prêteux, F.; Rebuffat, F. (eds.) Économies et sociétés en Grèce ancienne (478-88 av. J.-C.). Paris: A. Coulin, 2008, p. 212-234.

Pryor, J. H. Geographical Conditions of Galley Navigation in the Mediterranean. In: Gardiner, R. (ed.) The Age of the Galley. London: Conway Maritime, 1995, p. 206-216.

Rauh, N. Who Were the Cilician Pirates? In: Swiny, S. et al. (eds.) Res Maritimae: Cyprus and the Eastern Mediterranean from Prehistory to Late Antiquity Atlanta: Scholars Press, 1997, p. 263-283.

Rediker, M. Villains of All Nations: Atlantic Pirates in the Golden Age. Boston: Beacon, 2004. 
Rediker, M. The Slave Ship: A Human History. London: Penguin Books, 2007.

Rostovtzeff, M. The Social and Economic History of the Hellenistic World. Volume I. Oxford: Oxford University Press, 1941.

Roy, J. Cittadini ridotti in schiavitù: il consolidarsi della schiavitù nella Grecia classica. In: Di Nardo, A.; Lucchetta, G. A. (eds.) Nuove e antiche schiavitu. Napoli: Editoriale Scientifica, 2012, p. 53-63.

Şahin, S. Piratenüberfall auf Teos: Volksbeschluss über die Finanzierung der Erpressungsgelder. Epigraphica Anatolica, vol. 23, 1994, p. 1-36.

Scholten, J. The Politics of Plunder: Aitolians and their Koinon in the Early Hellenistic Era, 279-217 B.C. Berkeley: University of California Press, 2000.

Sekunda, N. A Note on the Rhodian Expedition against Aigila. Grammateion, vol. 3, 2014, p. 13-14.

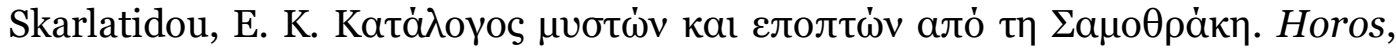
vol. 8-9, 1993, p. 153-172.

Sosin, J. Ransom at Athens ([Dem.] 53.11). Historia, vol. 66, 2017, p. 130-146.

Tsetskhladze, G. R. Black Sea Piracy. Talanta, vol. 32-33, 2000-2001, p. 308-315.

Velkov, V. Zur Frage der Sklaverei auf der Balkanhalbinsel während der Antike. Etudes Balkaniques, vol. 1, 1964, p. 125-138.

Vitkus, D. J. Piracy, Slavery, and Redemption: Barbary Captivity Narratives from Early Modern England. New York \& Chichester: Columbia University Press, 2001.

Vlassopoulos, K. Two Images of Ancient Slavery: The "Living Tool" and the "Koinônia". In: Hermann-Otto, E. (ed.) Sklaverei und Zwangsarbeit zwischen Akzeptanz und Widerstand. Hildesheim, Zürich \& New York: Olms Georg AG, 2011, p. 467-477.

van Wees, H. Status Warriors: War, Violence and Society in Homer and History. Amsterdam: J. C. Gieben, 1992.

. Ships and Silver, Taxes and Tribute: A Fiscal History of Archaic Athens. London: I. B. Tauris, 2013.

Wachsmann, S. Seagoing Ships \& Seamanship in the Bronze Age Levant. London: Texas A\&M University Press, 1998.

Wiemer, H.-U. Krieg, Handel und Piraterie: Untersuchungen zur Geschichte des hellenistischen Rhodos. Berlin: De Gruyter, 2002.

Zambon, E. I Provvidimenti ontro i pirati in età ellenistica. In: Braccesi, L. (ed.) La pirateria nell'Adriatico antico. Rome: L'Erma di Bretschneider, 2004, p. 147172. 